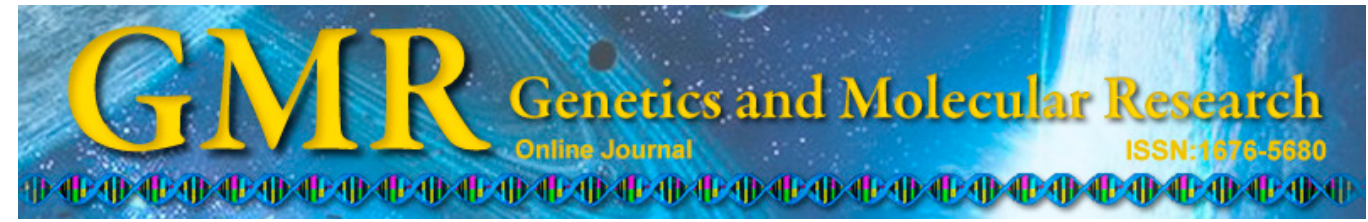

\title{
Association between SNPs in vascular endothelial growth factor polymorphisms and risk of renal cell carcinoma: a case-control study
}

\author{
B.-L. Shen, Q.-S. Qu, S.-Z. Miao and Y.-X. Zhang \\ Department of Renal Transplantation, Zhengzhou People's Hospital, \\ Zhengzhou, China \\ Corresponding author: B.-L. Shen \\ E-mail: shenbeili_zph2@163.com
}

Genet. Mol. Res. 14 (3): 11119-11125 (2015)

Received January 21, 2015

Accepted June 17, 2015

Published September 22, 2015

DOI http://dx.doi.org/10.4238/2015.September.22.5

\begin{abstract}
We conducted this case-control study to assess the role of the VEGF $-2578 \mathrm{C} / \mathrm{A},+1612 \mathrm{G} / \mathrm{A},+936 \mathrm{C} / \mathrm{T}$ and $-634 \mathrm{G} / \mathrm{C}$ gene polymorphisms in the development of renal cell carcinoma (RCC). A hospital-based case-control study was conducted in a 360 consecutive primary RCC patients and 360 age and gender-matched controls during January 2010 and January 2014. The polymerase chain reaction-restriction fragment length polymorphism was used for VEGF $-2578 \mathrm{C} / \mathrm{A},+1612 \mathrm{G} / \mathrm{A},+936 \mathrm{C} / \mathrm{T}$ and $-634 \mathrm{G} / \mathrm{C}$ genotyping. Multivariate conditional logistic regression analyses showed that subjects carrying the AA and the CA+AA genotypes of VEGF -2578C/A had significant association with increased risk of RCC compared to those having the CC genotype, and the ORs $(95 \% \mathrm{CI})$ were $1.77(1.10-2.85)$ and 1.37 (1.01-1.86), respectively. Using the conditional logistic regression model, CA+AA genotype of VEGF $-2578 \mathrm{C} / \mathrm{A}$ had a significantly increased risk of RCC in ever cigarette smokers, and individuals with hypertension, and the ORs $(95 \% \mathrm{CI})$ were $1.93(1.08-3.45)$ and
\end{abstract}


2.57 (1.06-6.57), respectively. In conclusion, our results showed that AA genotype of VEGF -2578C/A genetic variants is associated with increased risk of RCC.

Key words: Vascular endothelial growth factor; Polymorphism;

Renal cell carcinoma; Cancer risk

\section{INTRODUCTION}

In genitourinary cancers, renal cell carcinoma (RCC) has the highest mortality rate. It is a heterogeneous malignancy, and also revealed molecular and genetic heterogeneity and complexity (Tomaszewski et al., 2014). Clear cell renal cell carcinoma is the most popular histological subtype, accounting for approximately $80 \%$ of the cases of renal tumors (Farhadi et al., 2014). Early diagnosis and medical treatment seems important in decreasing mortality and increasing total quality of life. Several studies have suggested that genetic factors are involved in the development of RCC (Wang et al., 2014; Meng et al., 2014, 2015).

Angiogenesis is the formation of new blood vessels from pre-existing endothelium, and it is a discrete event in carcinogenesis which is correlated with the aggressive potential of a tumor (Hanahan and Folkman, 1996; Nakamura, et al., 2005). Increasing evidences have indicated that the growth of tumors is associated with increased angiogenesis, and formation of new blood vessels is a fundamental step in tumor development and expansion (Mariani et al., 2012). Vascular endothelial growth factor (VEGF) is a critical angiogenesis promoter, which is encoded by the VEGF gene (Hicklin and Ellis, 2005). It is reported that several common VEGF gene polymorphisms are associated with the development and progression of solid tumors, including 1154G/A (rs1570360), 2634G/C (rs2010963), and 2460C/T (rs833061) (Sun et al., 2013; Xu and Zhu, 2014; Jannuzzi et al., 2015).

Only three previous studies have reported the association between SNPs in VEGF and risk of RCC (Abe et al., 2002; Ajaz et al., 2011; Sáenz-López et al., 2013), but the findings of these studies are inconclusive. One recent meta-analysis have reported no correlation between six common SNPs in the VEGF gene and the development of RCC due to limited published studies (Zhang et al., 2013). Therefore, we conducted this case-control study to assess the role of the $-2578 \mathrm{C} / \mathrm{A},+1612 \mathrm{G} / \mathrm{A},+936 \mathrm{C} / \mathrm{T}$ and $-634 \mathrm{G} / \mathrm{C}$ gene polymorphisms in the development of RCC.

\section{MATERIAL AND METHODS}

\section{Study population}

A hospital-based case-control study was conducted in a 360 consecutive primary RCC patients and 360 age and gender-matched controls during January 2010 and January 2014 in the Zhengzhou People's Hospital. All RCC patients were newly diagnosed and histopathologically confirmed independently by two gynecologic pathologists. The criteria for RCC cases were those who had not yet received any chemotherapy or radiotherapy.

In total, 360 control subjects were randomly selected from individuals in the routine health examination center during the same period in Zhengzhou People's Hospital. All control subjects were found to be free of cancer. Each control was matched with a case by gender and 
age at enrollment (within \pm 5 years). All control subjects were confirmed to be lack of osteosarcoma, no history of any cancer, no family history of osteosarcoma in first degree relatives and a matched gender and age distribution with cases.

A written informed consent was obtained from each subject. The protocol of this study was previously approved by the ethics committee of Zhengzhou People's Hospital.

\section{DNA extraction and genotype analysis}

Each subject participant donated a 5-mL venous blood sample for genomic DNA extraction, which the blood was placed in $0.5 \mathrm{mg} / \mathrm{mL}$ EDTA anticoagulantcontained $0.5 \mathrm{mg} / \mathrm{mL}$ EDTA as anticoagulant, and the blood was stored atkept in $-20^{\circ} \mathrm{C}$ until usefurther usage. Genomic DNA was isolated from peripheral blood lymphocytes using Qiagen blood mini kit (Qiagen, Germany) by the manufacturer's protocol. The polymerase chain reaction-restriction fragment length polymorphism (PCR-RFLP) was used for VEGF -2578C/A, +1612G/A, +936C/T and $-634 \mathrm{G} / \mathrm{C}$ genotyping. The positive and reverse primers of these four were designed using the Sequenom Assay Design 3.1 software (Sequenom, San Diego, CA, USA). Forward and reverse primers were respectively as follows: for -2578C/A, 5'-TACTGGGGAGGTAACCTA GCAC-3' and 5'-GGAAAAATTCCTGGCTGGTT-3'; for +1612G/A, 5'-CACATGCTGCACG CGCATCTCA-3' and 5'-ACCCCAGGAAGGGGAGCAGGA-3'; for +936C/T, 5'-AGGGTTC GGGAACCAGATC-3' and 5'-CTCGGTGATTTAGCAGCAAG-3'; and for -634G/C, 5'-GAGAGAAGTCGAGGAAGAGAGA-3' and 5'-CCCAAAAGCAGGTCACTCACTT-3'. For PCR amplification, the standard program was used as follows: predenaturing $\left(94^{\circ} \mathrm{C}\right.$ for 5 min); denaturing $\left(94^{\circ} \mathrm{C}\right.$ for $\left.30 \mathrm{~s}\right)$; annealing $\left(55^{\circ} \mathrm{C}\right.$ for $\left.30 \mathrm{~s}\right)$; lengthening $\left(72^{\circ} \mathrm{C}\right.$ for $\left.45 \mathrm{~s}\right)$; total 35 cycles.

\section{Statistical analysis}

Continuous variables are reported as means $\pm \mathrm{SE}$, while categorical variables were shown as frequencies and percentages (\%). Differences in the distributions of demographic and clinical characteristics between cases and controls were comapred by the $\chi^{2}$-test. Deviations from Hardy-Weinberg equilibrium of the genotyped VEGF -2578C/A, +1612G/A, $+936 \mathrm{C} / \mathrm{T}$ and $-634 \mathrm{G} / \mathrm{C}$ genetic polymorphisms were evaluated by $\chi^{2}$-test. Multivariate conditional logistic regression analyses were used for evaluating the association between VEGF $-2578 \mathrm{C} / \mathrm{A},+1612 \mathrm{G} / \mathrm{A},+936 \mathrm{C} / \mathrm{T}$, and $-634 \mathrm{G} / \mathrm{C}$ genetic polymorphisms and $\mathrm{RCC}$ risk with adjustment for potential confounding factors, and the assessed results were calculated with odds ratio $(\mathrm{OR})$ and $95 \%$ confidence intervals $(\mathrm{CI})$. Gene-environmental interaction was evaluated by conditional logistic regression. A two-tailed $\mathrm{P}$ value of $<0.05$ was considered to be statistically significant. All the statistical analyses were conducted with the SPSS 19.0 statistical software (SPSS, Chicago, IL, USA).

\section{RESULTS}

The demographic and clinical characteristics of the study subjects are shown in Table 1. As expected, no significant differences were observed between the groups in terms of age and gender $(\mathrm{P}>0.05)$. Compared with the control subjects, the RCC patients were more likely 
to have a smoking habit and to suffer from diabetes. Of the 360 RCC patients, 303 (84.17\%) patients had I-II stage of RCC, 217 (60.28\%) had I-II grade of RCC, and $204(82.50 \%)$ were clear-cell RCC.

\begin{tabular}{|c|c|c|c|c|c|c|}
\hline Characteristics & Cases & $\%$ & Controls & $\%$ & $\chi^{2}$ & $P$ value \\
\hline Age, years (mean $\pm S D$ ) & $52.7 \pm 9.7$ & & $52.1 \pm 9.8$ & & & \\
\hline$<55$ & 199 & 55.28 & 192 & 53.33 & & \\
\hline$\geq 55$ & 161 & 44.72 & 168 & 46.67 & 0.27 & 0.61 \\
\hline \multicolumn{7}{|l|}{ Gender } \\
\hline Male & 236 & 65.56 & 236 & 65.56 & & \\
\hline Female & 124 & 34.44 & 124 & 34.44 & 0.00 & 1.00 \\
\hline \multicolumn{7}{|l|}{ Cigarette smoking } \\
\hline Never & 229 & 63.61 & 256 & 71.11 & & \\
\hline Ever & 131 & 36.39 & 104 & 28.89 & 4.61 & 0.03 \\
\hline \multicolumn{7}{|l|}{ Alcohol drinking } \\
\hline Never & 253 & 70.28 & 268 & 74.44 & & \\
\hline Ever & 107 & 29.72 & 92 & 25.56 & 1.56 & 0.21 \\
\hline \multicolumn{7}{|l|}{ Hypertension } \\
\hline No & 233 & 64.72 & 257 & 71.39 & & \\
\hline Yes & 127 & 35.28 & 103 & 28.61 & 3.68 & 0.06 \\
\hline \multicolumn{7}{|l|}{ Diabetes } \\
\hline No & 296 & 82.22 & 328 & 91.11 & & \\
\hline Yes & 64 & 17.78 & 32 & 8.89 & 12.31 & $<0.001$ \\
\hline \multicolumn{7}{|l|}{ Family history of cancer } \\
\hline Never & 330 & 91.67 & 341 & 94.72 & & \\
\hline Ever & 30 & 8.33 & 19 & 5.28 & 2.65 & 0.10 \\
\hline \multicolumn{7}{|l|}{ Stage } \\
\hline I-II & 303 & 84.17 & & & & \\
\hline III-IV & 57 & 15.83 & & & & \\
\hline \multicolumn{7}{|l|}{ Grade } \\
\hline I-II & 217 & 60.28 & & & & \\
\hline III-IV & 143 & 39.72 & & & & \\
\hline \multicolumn{7}{|l|}{ Histology } \\
\hline Clear cell & 297 & 82.50 & & & & \\
\hline Papillary & 16 & 4.44 & & & & \\
\hline Chromophobe & 24 & 6.67 & & & & \\
\hline Others & 23 & 6.39 & & & & \\
\hline
\end{tabular}

By $\chi^{2}$-test, genotype frequencies of VEGF $-2578 \mathrm{C} / \mathrm{A},+1612 \mathrm{G} / \mathrm{A}$, and $-634 \mathrm{G} / \mathrm{C}$ in controls demonstrated Hardy-Weinberg equilibrium, while +936C/T did not (Table 2). Multivariate conditional logistic regression analyses showed that subjects carrying the AA and the $\mathrm{CA}+\mathrm{AA}$ genotypes of $-2578 \mathrm{C} / \mathrm{A}$ had significant association with increased risk of RCC compared to those having the CC genotype, and the ORs $(95 \% \mathrm{CI})$ were $1.77(1.10-2.85)$ and 1.37(1.01-1.86) for the AA and the CA+AA genotypes, respectively. However, we did not find significant association between VEGF $+1612 \mathrm{G} / \mathrm{A},+936 \mathrm{C} / \mathrm{T}$ and $-634 \mathrm{G} / \mathrm{C}$ polymorphisms and risk of RCC $(\mathrm{P}>0.05)$.

In addition, we assessed the association between the VEGF -2578C/A polymorphism and demographic characteristics of RCC patients, including gender, age, cigarette smoking, alcohol drinking, hypertension, diabetes and family history of cancer (Table 3). Compared with CC genotype, CA+AA genotype of VEGF $-2578 \mathrm{C} / \mathrm{A}$ had a significantly increased risk of RCC in ever cigarette smokers, and individuals with hypertension, and the ORs $(95 \% \mathrm{CI})$ were 1.93 (1.08-3.45) and 2.57 (1.06-6.57) for ever cigarette smokers and individuals with hypertension, respectively. 


\begin{tabular}{|c|c|c|c|c|c|c|c|}
\hline VEGF genotypes & Cases & $\%$ & Controls & $\%$ & $\begin{array}{l}\text { P value for } \\
\text { Hardy-Weinberg equilibrium }\end{array}$ & $\begin{array}{c}\text { Adjusted } \\
\text { OR }(95 \% \mathrm{CI})^{1}\end{array}$ & $P$ value \\
\hline \multicolumn{8}{|l|}{$-2578 \mathrm{C} / \mathrm{A}$} \\
\hline $\mathrm{CC}$ & 150 & 41.67 & 178 & 49.44 & \multirow{4}{*}{0.11} & 1.0 (Ref.) & - \\
\hline $\mathrm{CA}$ & 149 & 41.39 & 141 & 39.17 & & $1.25(0.90-1.74)$ & 0.16 \\
\hline $\mathrm{AA}$ & 61 & 16.94 & 41 & 11.39 & & $1.77(1.10-2.85)$ & 0.01 \\
\hline $\mathrm{CA}+\mathrm{AA}$ & 210 & 58.33 & 182 & 50.56 & & $1.37(1.01-1.86)$ & 0.04 \\
\hline \multicolumn{8}{|l|}{$+1612 \mathrm{G} / \mathrm{A}$} \\
\hline GG & 152 & 42.22 & 166 & 46.11 & \multirow{4}{*}{0.23} & 1.0 (Ref.) & - \\
\hline $\mathrm{CA}$ & 170 & 47.22 & 164 & 45.56 & & $1.13(0.82-1.56)$ & 0.43 \\
\hline AA & 39 & 10.83 & 30 & 8.33 & & $1.42(0.81-2.49)$ & 0.19 \\
\hline $\mathrm{CA}+\mathrm{AA}$ & 209 & 58.06 & 194 & 53.89 & & $1.18(0.87-1.60)$ & 0.28 \\
\hline \multicolumn{8}{|l|}{$+936 \mathrm{C} / \mathrm{T}$} \\
\hline $\mathrm{CC}$ & 224 & 62.22 & 240 & 66.67 & \multirow{4}{*}{$<0.001$} & 1.0 (Ref.) & - \\
\hline CT & 81 & 22.50 & 73 & 20.28 & & $1.19(0.81-1.74)$ & 0.35 \\
\hline TT & 55 & 15.28 & 46 & 12.78 & & $1.28(0.81-2.02)$ & 0.26 \\
\hline $\mathrm{CT}+\mathrm{TT}$ & 136 & 37.78 & 119 & 33.06 & & $1.22(0.89-1.68)$ & 0.19 \\
\hline \multicolumn{8}{|l|}{$-634 \mathrm{G} / \mathrm{C}$} \\
\hline GG & 121 & 33.61 & 134 & 37.22 & \multirow{4}{*}{0.27} & 1.0 (Ref.) & - \\
\hline $\mathrm{GC}$ & 170 & 47.22 & 163 & 45.28 & & $1.15(0.82-1.62)$ & 0.39 \\
\hline $\mathrm{CC}$ & 69 & 19.17 & 63 & 17.50 & & $1.21(0.78-1.89)$ & 0.37 \\
\hline $\mathrm{GC}+\mathrm{CC}$ & 239 & 66.39 & 226 & 62.78 & & $1.17(0.85-1.61)$ & 0.31 \\
\hline
\end{tabular}

${ }^{1}$ Adjusted for gender, age, cigarette smoking, alcohol drinking, hypertension, diabetes, and family history of cancer in conditional logistic regression model.

Table 3. Stratification analyses between VEGF -2578C/A polymorphisms and risk of RCC.

\begin{tabular}{|c|c|c|c|c|c|c|c|c|}
\hline \multirow[t]{2}{*}{ Variables } & \multirow[t]{2}{*}{ Cases } & \multirow[t]{2}{*}{ Controls } & \multicolumn{2}{|c|}{ Cases } & \multicolumn{2}{|c|}{ Controls } & \multirow{2}{*}{$\frac{\text { Adjusted OR }(95 \% \mathrm{CI})^{1}}{\mathrm{CA}+\mathrm{AA} v s \mathrm{CC}}$} & \multirow[t]{2}{*}{$P$ value } \\
\hline & & & $\begin{array}{c}\mathrm{CC} \\
(\mathrm{N}=150\end{array}$ & $\begin{array}{c}\mathrm{CA}+\mathrm{AA} \\
(\mathrm{N}=210)\end{array}$ & $\begin{array}{c}\mathrm{CC} \\
(\mathrm{N}=178)\end{array}$ & $\begin{array}{c}\mathrm{CA}+\mathrm{AA} \\
(\mathrm{N}=182)\end{array}$ & & \\
\hline \multicolumn{9}{|c|}{ Age, years } \\
\hline$<55$ & 199 & 192 & 88 & 111 & 121 & 115 & $1.33(0.89-1.97)$ & 0.14 \\
\hline$\geq 55$ & 161 & 168 & 62 & 99 & 57 & 67 & $1.36(0.82-2.25)$ & 0.21 \\
\hline \multicolumn{9}{|l|}{ Gender } \\
\hline Male & 236 & 236 & 92 & 144 & 118 & 138 & $1.34(0.92-1.95)$ & 0.11 \\
\hline Female & 124 & 124 & 58 & 66 & 60 & 44 & $1.55(0.89-2.72)$ & 0.1 \\
\hline \multicolumn{9}{|c|}{ Cigarette smoking } \\
\hline Never & 229 & 256 & 89 & 141 & 120 & 148 & $1.28(0.88-1.87)$ & 0.17 \\
\hline Ever & 131 & 104 & 62 & 70 & 58 & 34 & $1.93(1.08-3.45)$ & 0.0003 \\
\hline \multicolumn{9}{|c|}{ Alcohol drinking } \\
\hline Never & 253 & 268 & 110 & 143 & 130 & 127 & $1.33(0.92-1.91)$ & 0.11 \\
\hline Ever & 107 & 92 & 40 & 67 & 48 & 55 & $1.46(0.81-2.63)$ & 0.18 \\
\hline \multicolumn{9}{|c|}{ Hypertension } \\
\hline No & 233 & 257 & 92 & 142 & 156 & 172 & $1.40(0.98-2.0)$ & 0.06 \\
\hline Yes & 127 & 103 & 59 & 69 & 22 & 10 & $2.57(1.06-6.57)$ & 0.02 \\
\hline \multicolumn{9}{|l|}{ Diabetes } \\
\hline No & 296 & 328 & 125 & 171 & 168 & 173 & $1.32(0.96-1.84)$ & 0.08 \\
\hline Yes & 64 & 32 & 25 & 39 & 10 & 9 & $1.73(0.54-5.55)$ & 0.29 \\
\hline \multicolumn{9}{|c|}{ Family history of cancer } \\
\hline Never & 330 & 341 & 139 & 191 & 168 & 173 & $1.33(0.97-1.83)$ & 0.06 \\
\hline Ever & 30 & 19 & 11 & 19 & 10 & 9 & $1.92(0.51-7.21)$ & 0.27 \\
\hline
\end{tabular}

${ }^{1}$ Adjusted for gender, age, cigarette smoking, alcohol drinking, hypertension, diabetes, and family history of cancer in conditional logistic regression model.

\section{DISCUSSION}

In the present study, we investigated the influence of VEGF $-2578 \mathrm{C} / \mathrm{A},+1612 \mathrm{G} / \mathrm{A}$, 
$+936 \mathrm{C} / \mathrm{T}$ and $-634 \mathrm{G} / \mathrm{C}$ in the VEGF gene on the risk of RCC, and examined the effect of geneenvironmental interaction on the development of this cancer in a Chinese population.

It is reported that angiogenesis is associated with the development of many tumors, and the VEGF is a potent regulator of angiogenesis and is involved in the carcinogenesis of solid tumors (Roy et al., 2006; Kushner and Bautch, 2013) The expression of VEGF could promote endothelial cell proliferation and remodel the extracellular matrix in the blood vessels (Ferrara, 2002), and functional gene variations of the VEGF gene could influence the gene expression and the plasma VEGF levels, and thus the accelerated process of carcinogenesis (Ajaz et al., 2011; Sáenz-López et al., 2013; Zhang et al., 2013).

Previous studies reported the association between polymorphisms in VEGF -2578C/A and risk of cancer (Tie et al., 2014; Zidi et al., 2014; Machado et al., 2014; Deng et al., 2014; Chen et al., 2014). A case-control study in a Chinese population suggested that VEGF $-2578 \mathrm{C} / \mathrm{A}$ polymorphism plays an important role in the pathogenesis of osteosarcoma (Tie et al., 2014). Another case-control study investigated the association between common SNPs in VEGF and risk of cervical cancer in a Tunisian population, and it suggested that VEGF -2578C/A polymorphism may contribute to the development of cervical cancer (Zidi et al., 2014). In a case-control study in a Portuguese population, findings suggested that VEGF $-2578 \mathrm{C} / \mathrm{A}$ polymorphism was associated with an increased risk of hepatocellular carcinoma (Machado et al., 2014). In a case-control study in a Chinese population, it reported an association between VEGF -2578AA genotypes and increased risk of lung cancer (Deng et al., 2014). However, some studies reported inconsistent results (Sa-Nguanraksa et al., 2013). In a case-control study in a Thai population, it did not find significant association between VEGF -2578C/A polymorphism and breast cancer risk (Sa-Nguanraksa et al., 2013; Sáenz-López et al., 2013). In a meta-analysis regarding the association between VEGF -2578C/A and cancer risk, this study indicates that VEGF -2578C/A polymorphism was only associated with the risk of colorectal cancer and lung cancer (Chen et al., 2014). The discrepancies between previous epidemiological studies could be due to differences in populations, source of included cases and controls, sample size, study design and also by chance.

For the association between VEGF -2578C/A polymorphism and risk of RCC, two previous studies reported their association (Ajaz et al., 2011; Sáenz-López et al., 2013). Ajaz et al. (2011) reported that VEGF -2578 A-allele and A-carrier genotypes were correlated with increased risk of RCC in a Pakistani population. However, another case-control study in a Spanish population suggested that VEGF -2578C/A polymorphism does not appear to exert a significant risk of RCC (Sáenz-López et al., 2013). In a recent meta-analysis, Zhang et al. reported that VEGF gene polymorphisms may be not associated with an increased risk of RCC (Zhang et al., 2013). Further large sample studies are greatly needed to confirm our finding.

In conclusion, our results showed that AA genotype of VEGF -2578C/A genetic variants is associated with increased risk of RCC, and a significant interaction was found between VEGF -2578C/A polymorphism and smoking and hypertension. Further investigations on the role of VEGF gene polymorphisms on the risk of RCC are greatly needed.

\section{REFERENCES}

Abe A, Sato K, Habuchi T, Wang L, et al. (2002). Single nucleotide polymorphisms in the $3^{\prime}$ untranslated region of vascular endothelial growth factor gene in Japanese population with or without renal cell carcinoma. Tohoku J. Exp. Med. 198: 181-190. 
Ajaz S, Khaliq S, Abid A, Hassan AS, et al. (2011). Association of a single-nucleotide polymorphism in the promoter region of the VEGF gene with the risk of renal cell carcinoma. Genet. Test Mol. Biomarkers 15: 653-657.

Chen Q, Zhou Z, Shan L, Hua Y, et al. (2014). Association of the vascular endothelial growth factor $-2578 \mathrm{C} / \mathrm{A}$ polymorphism with cancer risk: A meta-analysis update. Biomed Rep. 2: 823-830.

Deng ZC, Cao C, Yu YM, Ma HY, et al. (2014). Vascular endothelial growth factor -634G/C and vascular endothelial growth factor -2578C/A polymorphisms and lung cancer risk: a case-control study and meta-analysis. Tumour Biol. 35: 1805-1811.

Farhadi A, Behzad-Behbahani A, Geramizadeh B, Sekawi Z, et al. (2014). High-risk human papillomavirus infection in different histological subtypes of renal cell carcinoma. J. Med. Virol. 7: 1134-1144.

Ferrara N (2002). VEGF and the quest for tumour angiogenesis factors. Nat. Rev. Cancer 2: 795-803.

Hanahan D and Folkman J (1996). Patterns and emerging mechanisms of the angiogenic switch during tumorigenesis. Cell 86: 353-64.

Hicklin DJ and Ellis LM (2005). Role of the vascular endothelial growth factor pathway in tumor growth and angiogenesis. J. Clin. Oncol. 23: 1011-1027.

Jannuzzi AT, Özhan G, Yanar HT and Alpertunga B (2015). VEGF gene polymorphisms and susceptibility to colorectal cancer. Genet. Test Mol. Biomarkers 19: 133-137.

Kushner EJ and Bautch VL (2013). Building blood vessels in development and disease. Curr. Opin. Hematol. 20: 231-236.

Machado MV, Janeiro A, Miltenberger-Miltenyi G and Cortez-Pinto H (2014). Genetic polymorphisms of proangiogenic factors seem to favor hepatocellular carcinoma development in alcoholic cirrhosis. Eur. J. Gastroenterol. Hepatol. 26: $438-443$

Mariani BM, Trarbach EB, Ribeiro TC, Pereira MA, et al. (2012). Genotype analysis of the human endostatin variant p.D104N in benign and malignant adrenocortical tumors. Clinics 67: 95-98.

Meng F, Ma P, Sui C, Tian X, et al. (2014). The association between VDR polymorphisms and renal cell carcinoma susceptibility: a meta-analysis. Tumour Biol. 35: 6065-6072.

Meng FD, Ma P, Sui CG, Tian X, et al. (2015). Association between cytochrome P450 1A1 (CYP1A1) gene polymorphisms and the risk of renal cell carcinoma: a meta-analysis. Sci. Rep. 5: 8108.

Nakamura Y, Yasuoka H, Tsujimoto M, Imabun S, et al. (2005). Lymph vessel density correlates with nodal status, VEGF-C expression, and prognosis in breast cancer. Breast Cancer Res. Treat. 91: 125-132.

Roy H, Bhardwaj S and Yla-Herttuala S (2006). Biology of vascular endothelial growth factors. FEBS Lett. 580: 2879-2887.

Sáenz-López P, Vazquez F, Cozar JM, Carretero R, et al. (2013). VEGF polymorphisms are not associated with an increased risk of developing renal cell carcinoma in Spanish population. Hum. Immunol. 74: 98-103.

Sa-Nguanraksa D, Chuangsuwanich T, Pongpruttipan T, Kummalue T, et al. (2013). Vascular endothelial growth factor $-634 \mathrm{G} / \mathrm{C}$ polymorphism is associated with increased breast cancer risk and aggressiveness. Mol. Med. Rep. 8: 1242-1250.

Sun SF, Huang DB, Cao C and Deng ZC (2013). Polymorphism of VEGF-460C/T associated with the risk and clinical characteristics of lung cancer in Chinese population. Med. Oncol. 30: 410.

Tie Z, Bai R, Zhai Z, Zhang G, et al. (2014). Single nucleotide polymorphisms in VEGF gene are associated with an increased risk of osteosarcoma. Int. J. Clin. Exp. Pathol. 7: 8143-8149.

Tomaszewski JJ, Uzzo RG and Smaldone MC (2014). Heterogeneity and renal mass biopsy: a review of its role and reliability. Cancer Biol. Med. 1: 162-172.

Wang Z, Wei M, Ren Y, Liu H, et al. (2014). miR149 rs71428439 polymorphism and risk of clear cell renal cell carcinoma: a case-control study. Tumour Biol. 35: 12127-12130.

$\mathrm{Xu} \mathrm{Y}$ and Zhu S (2014). Associations between vascular endothelial growth factor polymorphisms and prostate cancer risk: a meta-analysis. Tumour Biol. 35: 1307-1311.

Zhang Y, Li S, Xiao HQ, Hu ZX, et al. (2013). Vascular endothelial growth factor gene polymorphisms and renal cell carcinoma: A systematic review and meta-analysis. Oncol. Lett. 6: 1068-1078.

Zidi S, Stayoussef M, Gazouani E, Mezlini A, et al. (2014). Relationship of common vascular endothelial growth factor polymorphisms and haplotypes with the risk of cervical cancer in Tunisians. Cytokine S1043-4666(14)00592-4. 